Ilmu Pertanian (Agricultural Science)

Vol. 1 No.2 August, 2016 : 047-054

Available online at http://journal.ugm.ac.id/jip

DOI: doi.org/ 10.22146/ipas.9139

\title{
Effects of Herbicide Application Timing and Tillage System on Tobacco Plant (Nicotiana tabacum L.)
}

\author{
Vanindyantara Nugra Pratama \\ Graduate School of Crop Science, Faculty of Agriculture, Universitas Brawijaya \\ Jln. Veteran, Malang 65145, Jawa Timur, Indonesia \\ *Corresponding email: vanindya1989@gmail.com
}

Received:3 ${ }^{\text {rd }}$ February 2016 ; Revised: $1^{\text {st }}$ March 2016 ; Accepted: $22^{\text {th }}$ March 2017

\begin{abstract}
This research aims to study the result of proper glyphosate and paraquat application and tillage system as weed controller and to get the proper herbicide application timing and soil tillage system for increased growth and yield of tobacco. The research was conducted in Pakel Village, Sumberpucung District, Malang Regency in July-October 2014. Method used in the research was Split-Plot design with 2 levels of tillage system as main plot and 6 levels of application herbicide timing as sub-plot with 3 replications. Glyphosate application before planting increased growth factor of tobacco i.e. number of leaves, plant height, and leaf area. Glyphosate application before tillage and planting increased yield factor of tobacco i.e. fresh weight of roots and stems, fresh weight of leaves, dry weight of chopped tobacco, and nicotine content.
\end{abstract}

Keywords: Glyphosate, Paraquat, Tobacco Plant, Weed

\section{INTRODUCTION}

Tobacco is a commodity playing an important role for the country's economy, as a source of income. From cigarette industry, tobacco is able to provide income from the tax approximately one trillion annually. This number is the biggest amount among all of the taxes received by the government. Total consumption of local tobacco by cigarette industry is still showing escalation. With area reaching 2,900 ha in 2012 and 2013 (BPS, 2013), tobacco plantation produced yield of 260,818 and 276,000 ton respectively (Ditjenbun, 2013). Based on those data, it can be inferred that there was an increase in tobacco's production. The yield improvements were commonly done by adding fertilizer either organic or inorganic. The increasing of production which is specifically obtained by intensification such as weed control and tillage has not been frequently applied yet. Weed growing during tobacco's culture will directly compete to get required growth factor like water, sunlight, and nutrient. The application of proper herbicide in the right time is known to be able to minimize the weed growth.

Mechanical control is an effort to suppress weed growth by destroying its parts resulting death or retardation. Weed control is mechanically done by repetitious tillage using tractor and manual weeding utilizing tools like hoe. Weed control technique is generally quite good to be done for annual weed, but in some cases it is also effective for perennial weeds (Sukma and Yakup, 1992).

Weed growing in tobacco's plantation area consists of grasses, sedges, and broad leaf weeds (low percentage). The dominant type is narrow leaf weeds included into sedges called nut grass (Cyperus rotundus) and some of them are grasses namely Bermuda grass (Cynodon dactylon). Besides to control weeds, tillage is also done for plant cultivation to optimize the crop's growth. Weed control which is done after tobacco planting by manual removal is effective since we can do both tillage and weed control at once to provide aeration to enhance mineral absorption for optimum growth.

Based on those problems, it is necessary to conduct research about the effectivity of herbicide application and tillage system to improve quality and quantity of tobacco's yield production. 


\section{MATERIALS AND METHODS}

This research was conducted in July-October 2014 in Pakel Village, Sumberpucung District, Malang Regency which is located at $303 \mathrm{~m}$ asl with minimum temperature of $18-21^{\circ} \mathrm{C}$ and maximum temperature of $30-33^{\circ} \mathrm{C}$. The precipitation is around $100 \mathrm{~mm} / \mathrm{month}$. The soil type is Alfisol with $\mathrm{pH}$ of 6-6.2.

Equipments used in this research were including: hoe, metre, seeder, raffia fibre, analytics balance, ruler, paper, millimeter block, and camera. While materials used were tobacco's seed type Virginia cv. Coker 176. Post-planting herbicide applied before planting, Roundup, containing isopropylamine glyphosate $486 \mathrm{~g}^{-1}$, post-planting herbicide, Gramoxone, containing paraquat dichloride $276 \mathrm{~g} \mathrm{l}^{-1}$, ZA fertilizer, $\mathrm{KNO}_{3}$, and foliar fertilizer.

This research used Split-Plot design with three replications. Tillage system (T), as main plot, consisted of two levels that were: $\mathrm{T} 1=$ minimum application of tillage; $\mathrm{T} 2=$ maximum application of tillage. As sub-plots, herbicide application timing (H) consisted of: $\mathrm{H} 0=$ without herbicide; $\mathrm{H} 1=$ paraquat herbicide applied before tillage; $\mathrm{H} 2=$ glyphosate herbicide applied before tillage; $\mathrm{H3}=$ paraquat herbicide applied before planting; $\mathrm{H} 4=$ glyphosate herbicide applied before planting; H5 = combination of glyphosate dan paraquat herbicide applied before planting.

Variables observed in this research were: SDR (Summed Dominance Ratio) and dry weight of the weed before tillage and at 14, 28, 42, 56, 70, and 84 days after planting; Plant height, which was measured from soil surface to growth point; Number of leaves, which was obtained by counting number of perfect-developed leaves; Leaf area using gravimetry method; Fresh weight of roots, stems, and leaves (gram); Nicotine content (\%).

Observation data which were obtained were analysed using analysis of varians (F test) at $5 \%$. If the result shows significant difference, then the test is continued to comparation test among treatments using Least Significant Difference (LSD) at 5\%.

\section{RESULT AND DISCUSSION}

\section{SDR and dry weight of weed}

Based on vegetation analysis conducted before tillage, weed species growing on the field were classified into broad leaf weeds, narrow leaf weeds, grasses, and sedges. Dominant species found on the field ( $5^{\text {th }}$ score with $31-50 \%$ of land coverage) was Portulaca oleracea (44.12\%). Other weeds such as Cyperus rotundus and Euphorbia hirta were at $3^{\text {rd }}$ score (11-30\%). While Digitaria sanguinalis and Ageratum conyzoides were only at $1^{\text {st }}$ score (1$10 \%)$ (Figure 1).

On the weed observation at harvest, it was found that there was a change on the weed's growth characterized by the emmersion of species which were not found before research until the time of the tillage and herbicide application. The species found were: Physallis minima, Bidens pilosa, Sonchus oleraceus, and Chromolaena odorata. Those species were found growing on the field with maximum tillage treatment without herbicide with SDR of $6.63 \%, 5.59 \%, 6.63 \%$, and $6.11 \%$ consecutively. $B$. pilosa was also found on the field with maximum

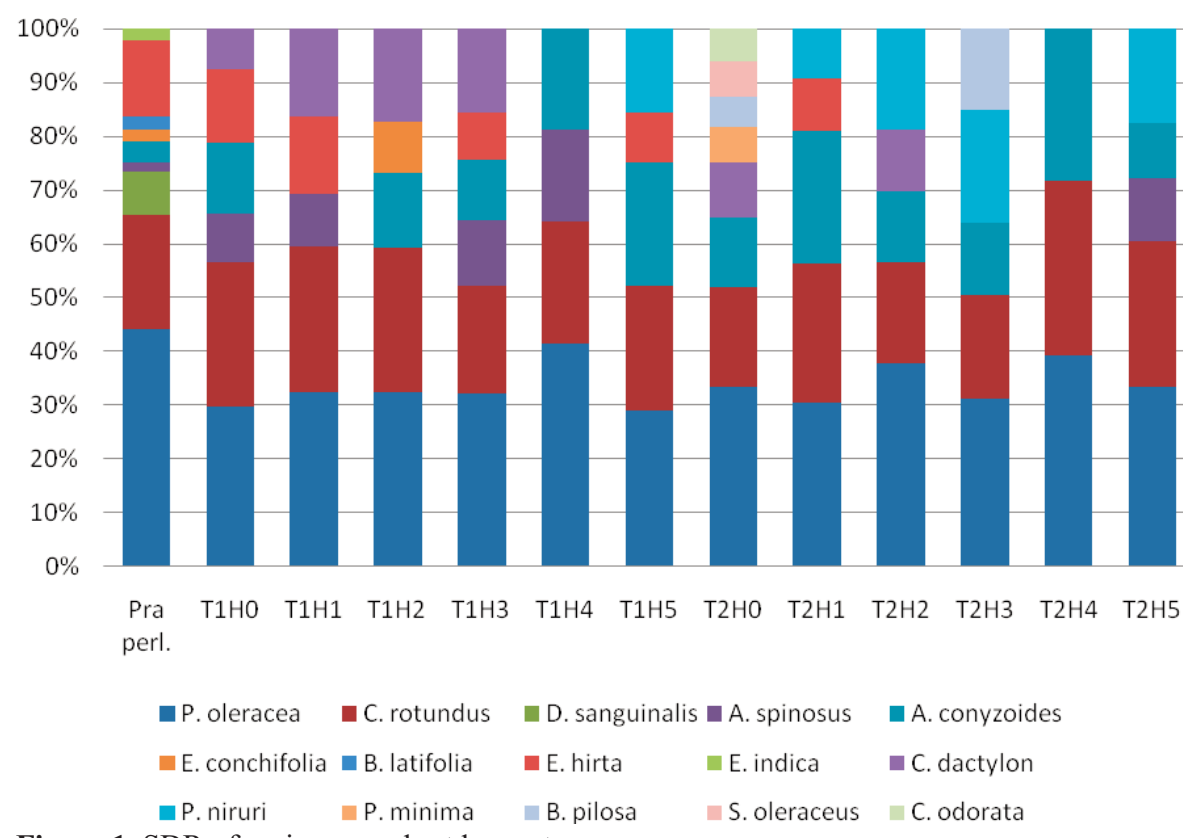

Figure 1. SDR of various weeds at harvest 
Table 1. Dry weight of the weeds $\left(\mathrm{g} 2500 \mathrm{~cm}^{-2}\right)$ affected by the interaction of tillage system and herbicide application

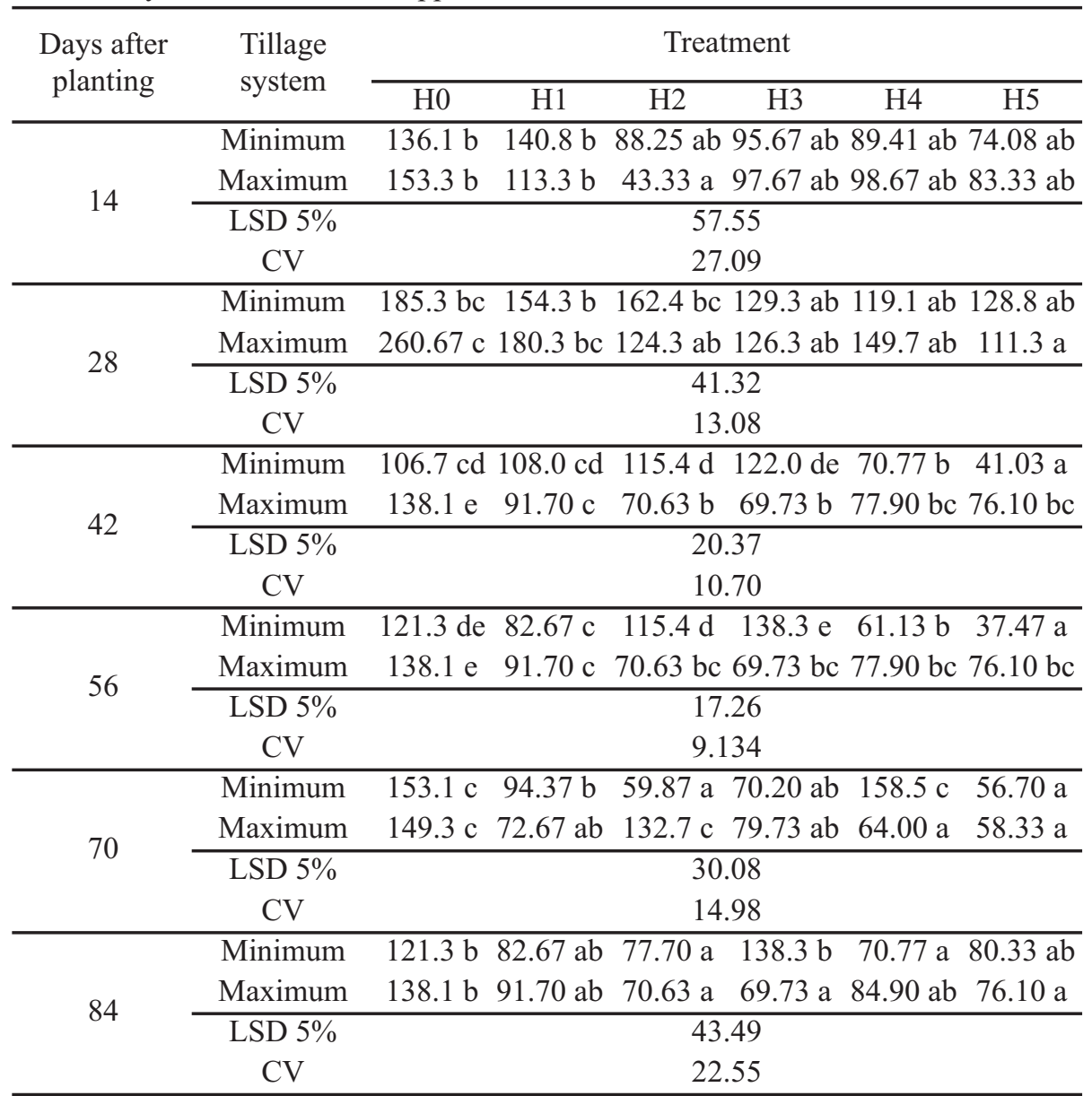

Remarks: Number followed by the same letter in the same period (days after planting) doesn't show any significant difference based on LSD test at 5\%; H0: without herbicide; H1: paraquat herbicide before tillage; H2: paraquat herbicide before planting; $\mathrm{H} 3$ : glyphosate herbicide before tillage; H4: glyphosate herbicide before planting; H5: paraquat + glyphosate herbicide before planting.

tillage combined with paraquat herbicide applied before planting $\left(\mathrm{H}_{3}\right)$ with SDR of $15.21 \%$.

Besides the growth of the weeds which was not found before treatments, there were some species which did not grow at harvest. D. sanguinalis which was found to have SDR of $8.06 \%$ before treatments did not grow at harvest. The same thing happened to E. indica and B. latifolia which had SDR each of $2.27 \%$ and $2.16 \%$ before treatments. At the end of observation, the weeds growing dominantly (SDR $>15 \%$ ) were P. oleracea, C. rotundus, A. spinosus, A. conyzoides, $C$. dactylon, $P$. niruri and B. pilosa.

P. oleracea and $C$. rotundus were always dominant in all treatments and observation period. It related to their characteristic where $P$. oleracea is able to propagate by stem fragments rooting when it grows in logged soil (Holm et al., 1972). While C. rotundus reproduces rapidly with its tuber (Blum et al., 1987).

The weed growth is affected by environment condition i.e. lighting and shading. The low dry weight of the weeds was caused by the limited growing space for the weeds and sunlight which could be used to do photosynthesis. This result was in accordance with Moenandir (2004).

Based on the observation at harvest, it can be explained that combination between tillage and herbicide application was not quite significant to suppress the weeds growth. SDR values of $P$. oleracea, C. rotundus, A. spinosus, A. conyzoides, and E. hirta in some treatments were higher than those before treatments. The combination of tillage and herbicide application was effective only to suppress the growth of $D$. sanguinalis, B. latifolia, and $E$. indica. This result was supported by Tjitrosoedirdjo et al. (1984) who stated that paraquat herbicide is a contact herbicide from the group of bipiridilium used to control weeds or for post-growth application. This herbicide is used to control seasonal weeds especially grasses. However, at the observation during harvest time, it was found that there were new species growing i.e. B. pilosa, S. oleraceus, and C. odorata. B. pilosa 
Table 2. Tobacco's plant height $(\mathrm{cm})$ influenced by interaction of tillage system and herbicide application

\begin{tabular}{|c|c|c|c|c|c|c|c|}
\hline \multirow{2}{*}{$\begin{array}{l}\text { Days after } \\
\text { planting }\end{array}$} & \multirow{2}{*}{$\begin{array}{l}\text { Tillage } \\
\text { system }\end{array}$} & \multicolumn{6}{|c|}{ Treatment } \\
\hline & & $\mathrm{H} 0$ & $\mathrm{H} 1$ & $\mathrm{H} 2$ & $\mathrm{H} 3$ & $\mathrm{H} 4$ & $\mathrm{H} 5$ \\
\hline \multirow{4}{*}{28} & Minimum & $18.56 \mathrm{ab}$ & $17.17 \mathrm{a}$ & $19.89 \mathrm{ab}$ & $17.17 \mathrm{a}$ & $19.00 \mathrm{ab}$ & $21.78 \mathrm{~b}$ \\
\hline & Maximum & $17.67 \mathrm{ab}$ & $23.28 \mathrm{~b}$ & $20.83 \mathrm{ab}$ & $22.11 \mathrm{~b}$ & $17.33 \mathrm{a}$ & $21.00 \mathrm{ab}$ \\
\hline & LSD 5\% & \multicolumn{6}{|c|}{4.206} \\
\hline & $\mathrm{CV}$ & \multicolumn{6}{|c|}{10.201} \\
\hline \multirow{4}{*}{70} & Minimum & $73.67 \mathrm{a}$ & $82.00 \mathrm{~b}$ & $85.00 \mathrm{bc}$ & $83.00 \mathrm{~b}$ & $81.33 \mathrm{ab}$ & $94.00 \mathrm{c}$ \\
\hline & Maximum & $82.33 \mathrm{~b}$ & $85.00 \mathrm{bc}$ & $86.00 \mathrm{bc}$ & $92.00 \mathrm{c}$ & $75.67 \mathrm{ab}$ & $88.33 b c$ \\
\hline & LSD 5\% & \multicolumn{6}{|c|}{8.255} \\
\hline & $\mathrm{CV}$ & \multicolumn{6}{|c|}{4.681} \\
\hline \multicolumn{8}{|c|}{$\begin{array}{l}\text { Remarks: Number followed by the same letter in the same period (days after planting) doesn't } \\
\text { show any significant difference based on LSD test at 5\%; H0: without herbicide; H1: } \\
\text { paraquat herbicide before tillage; H2: paraquat herbicide before planting; H3: } \\
\text { glyphosate herbicide before tillage; H4: glyphosate herbicide before planting; H5: } \\
\text { paraquat+glyphosate herbicide before planting. }\end{array}$} \\
\hline
\end{tabular}

Table 3. Tobacco's plant height $(\mathrm{cm})$ influenced by tillage system and herbicide application

\begin{tabular}{|c|c|c|c|c|}
\hline \multirow{2}{*}{ Treatment } & \multicolumn{4}{|c|}{ Number of leaves at various days after planting } \\
\hline & 14 & 42 & 56 & 84 \\
\hline \multicolumn{5}{|l|}{ Tillage system: } \\
\hline Minimum & 7.731 & 43.57 & 61.28 & 87.39 \\
\hline Maximum & 8.065 & 43.68 & 58.28 & 90.83 \\
\hline LSD 5\% & ns & ns & ns & ns \\
\hline $\mathrm{CV}$ & 12.66 & 0.76 & 15.06 & 11.59 \\
\hline \multicolumn{5}{|c|}{ Herbicide application: } \\
\hline H0 & 8.000 & $41.67 \mathrm{ab}$ & 63.33 & $76.17 \mathrm{a}$ \\
\hline H1 & 8.167 & $42.33 \mathrm{ab}$ & 55.17 & $96.83 \mathrm{~b}$ \\
\hline $\mathrm{H} 2$ & 7.639 & $43.11 \mathrm{ab}$ & 61.83 & $93.50 \mathrm{~b}$ \\
\hline H3 & 7.556 & $44.61 \mathrm{~b}$ & 60.17 & $82.83 \mathrm{ab}$ \\
\hline H4 & 7.583 & $39.83 \mathrm{a}$ & 56.00 & $87.33 \mathrm{ab}$ \\
\hline H5 & 8.444 & $50.22 \mathrm{c}$ & 62.17 & $98.00 \mathrm{~b}$ \\
\hline LSD 5\% & ns & 3.75 & ns & 8.41 \\
\hline CV & 21.51 & 20.19 & 13.98 & 23.58 \\
\hline \multicolumn{5}{|c|}{$\begin{array}{l}\text { Remarks: Number followed by the same letter in the same column doesn't show any signif- } \\
\text { icant difference based on LSD test at 5\%; H0: without herbicide; H1: paraquat her- } \\
\text { bicide before tillage; H2: paraquat herbicide before planting; H3: glyphosate } \\
\text { herbicide before tillage; H4: glyphosate herbicide before planting; H5: } \\
\text { paraquat+glyphosate herbicide before planting. }\end{array}$} \\
\hline
\end{tabular}

can produce 6000 seeds in a life cycle and survive up to 4 years (Waterhouse, 1994). S. oleraceus has competitive ability towards other weeds by releasing phenolic substances which are soluble in water and allelopathic for other weeds. Hence, the persistence of this kind of weed was quite high at harvest time (Hassan et al., 2014).

Based on the dry weight observation, it can be inferred that maximum tillage increased weed growth suppression up to $12 \%$ compared to minimum tillage. Paraquat and glyphosate herbicide application before tillage decreased dry weight each $41.6 \%$ and $48.8 \%$ compared o treatment without herbicide. Weed control is said to be effective if total dry weight of the weeds is low. Herbicide application both before tillage and before planting combined with either minimum or maximum tillage could suppress dry weight of the weeds up to twice at 14 days after planting and it increased to threefold at harvest. Total dry weight of the weeds is the right measurement to know the amount of the source absorbed by them. The weeds growth is affected environment condition such as lighting and shading. The low dry weight of the weight was also caused by the limited growing space and sunlight for photosynthesis. This result was in line with the statement of Moenandir (2004).

\section{Plant Height}

The result of analysis of varians showed that 
Table 4. Number of leaves affected by interaction of tillage system and herbicide application

\begin{tabular}{|c|c|c|}
\hline \multirow{2}{*}{$\begin{array}{c}\text { Days after } \\
\text { planting }\end{array}$} & \multirow{2}{*}{$\begin{array}{l}\text { Tillage } \\
\text { system }\end{array}$} & Treatment \\
\hline & & $\mathrm{H} 3$ \\
\hline \multirow{4}{*}{28} & Minimum & $5.333 \mathrm{ab} 5.111 \mathrm{ab} 5.000 \mathrm{ab} 5.222 \mathrm{ab} 5.333 \mathrm{ab} 5.667 \mathrm{~b}$ \\
\hline & Maximum & $4.333 \mathrm{a} \quad 6.667 \mathrm{~b} \quad 5.778 \mathrm{~b} \quad 5.778 \mathrm{~b} \quad 5.111 \mathrm{ab} \quad 6.000 \mathrm{~b}$ \\
\hline & LSD 5\% & 1.226 \\
\hline & $\mathrm{CV}$ & 10.81 \\
\hline \multirow{4}{*}{42} & Minimum & 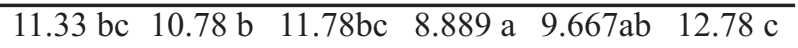 \\
\hline & Maximum & 11.78 bc 12.22 bc 13.56 c $12.44 b c \quad 1278$ c $12.11 b c$ \\
\hline & LSD 5\% & 1.747 \\
\hline & $\mathrm{CV}$ & 7.131 \\
\hline \multirow{4}{*}{56} & Minimum & $16.00 \mathrm{~b} \quad 15.11 \mathrm{~b} \quad 16.00 \mathrm{~b} \quad 14.44 \mathrm{ab} \quad 14.33 \mathrm{ab} \quad 12.33 \mathrm{a}$ \\
\hline & Maximum & $13.67 \mathrm{ab} 14.11 \mathrm{ab} \quad 15.33 \mathrm{~b} \quad 15.00 \mathrm{ab} \quad 16.33 \mathrm{~b} \quad 14.67 \mathrm{ab}$ \\
\hline & LSD 5\% & 2.673 \\
\hline & $\mathrm{CV}$ & 8.621 \\
\hline \multirow{4}{*}{70} & Minimum & $18.33 \mathrm{~b} \quad 16.67 \mathrm{ab} \quad 17.61 \mathrm{~b} \quad 16.67 \mathrm{ab} \quad 15.61 \mathrm{a} \quad 16.00 \mathrm{ab}$ \\
\hline & Maximum & $16.00 \mathrm{ab} 16.67 \mathrm{ab} 15.94 \mathrm{ab} 16.67 \mathrm{ab} 16.72 \mathrm{ab} 17.33 \mathrm{ab}$ \\
\hline & LSD 5\% & 1.924 \\
\hline & $\mathrm{CV}$ & 5.494 \\
\hline \multirow{4}{*}{84} & Minimum & 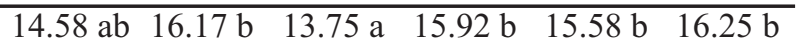 \\
\hline & Maximum & $15.25 \mathrm{ab} 14.75 \mathrm{ab} 15.25 \mathrm{ab} 15.42 \mathrm{ab} 14.25 \mathrm{ab} 14.17 \mathrm{ab}$ \\
\hline & LSD 5\% & 1.773 \\
\hline & $\mathrm{CV}$ & 5.591 \\
\hline \multicolumn{3}{|c|}{$\begin{array}{l}\text { Remarks: Number followed by the same letter in the same period (days after planting) doesn't } \\
\text { show any significant difference based on LSD test at 5\%; H0: without herbicide; H1: } \\
\text { paraquat herbicide before tillage; H2: paraquat herbicide before planting; H3: } \\
\text { glyphosate herbicide before tillage; H4: glyphosate herbicide before planting; H5: } \\
\text { paraquat+glyphosate herbicide before planting. }\end{array}$} \\
\hline
\end{tabular}

there was interaction between tillage system and herbicide application at 28 and 70 days after planting. The average of plant height influenced by the interaction is presented on table 2 . While the mean of plant height affected by tillage system and herbicide application is performed on table 3 .

\section{Number of leaves}

The result of analysis of varians illustrated that there was intraction between tillage system and herbicide application at $28,42,56,70$, and 84 days after planting (table 4).

Based on the research, the growth of tobacco's plant was not only affected by tillage system but also herbicide application. The application of glyphosate herbicide gave better result on the number of leaves reaching $2.1-13.6 \%$ and $6.5-9.8 \%$ on the plant height compared to the application of paraquat herbicide. This result was agreed by Chinery (2002), Daud (2004), and Listyobud (2011) who mentioned that systemic herbicide can control weeds better than contact herbicide. The use of herbicide especially systemic herbicide in higher concentration and dosage gives better effect to the growth of the plant indicated by plant height, number of leaves, leaf area, and total dry weight due to low competition.

Generally, maximum tillage system gave better result up to $8-33 \%$ compared to minimum tillage system for each variable of observation. Soil structure plays role in maintaining moisture and air penetration, thus, soil structure also affected the growth and development of the plant. On the other side, every type of tobacco's plant requires specific soil to produce optimum quality (Tso, 1990).

\section{Leaf area}

The result of analysis of varians showed that there was interaction between tillage system and herbicide application at 28, 42, 56, 70, and 84 days after planting (table 5).

\section{Fresh weight of stems and roots}

The result of analysis of varians illustrated that there was interaction between tillage system and herbicide application on fresh weight of stems and roots of tobacco's plant (table 6).

The result showed that maximum tillage system gave better result around 18\% compared to minimum tillage system. While the combination of paraquat + glyphosate herbicide application gave positive effects 
Table 5. Leaf area $\left(\mathrm{cm}^{2}\right.$ plant $\left.{ }^{-1}\right)$ affected by interaction between tillage system and herbicide application

\begin{tabular}{|c|c|c|c|c|}
\hline \multirow{2}{*}{$\begin{array}{c}\text { Days after } \\
\text { planting }\end{array}$} & \multirow{2}{*}{$\begin{array}{l}\text { Tillage } \\
\text { system }\end{array}$} & \multicolumn{3}{|c|}{ Treatment } \\
\hline & & H0 & $\begin{array}{ll}\mathrm{H} 2 & \mathrm{H} 3\end{array}$ & H5 \\
\hline \multirow{4}{*}{14} & Minimum & $6.302 \mathrm{a}$ & $7.139 \mathrm{ab} \quad 6.077 \mathrm{a}$ & $10.04 \mathrm{~b}$ \\
\hline & Maximum & $9.401 \mathrm{~b}$ & $8.622 \mathrm{~b}$ & $9.708 \mathrm{~b}$ \\
\hline & LSD 5\% & \multicolumn{3}{|c|}{2.201} \\
\hline & $\mathrm{CV}$ & \multicolumn{3}{|c|}{13.14} \\
\hline \multirow{4}{*}{28} & Minimum & 168.9ab 197.5ab & $242.6 \mathrm{~b} \quad 148.1 \mathrm{ab} \quad 264.0 \mathrm{~b}$ & $284.5 \mathrm{~b}$ \\
\hline & Maximum & $125.5 \mathrm{a} \quad 211.9 \mathrm{~b}$ & $195.7 \mathrm{ab} \quad 243.7 \mathrm{~b} \quad 205.0 \mathrm{ab}$ & $296.2 \mathrm{~b}$ \\
\hline & LSD 5\% & \multicolumn{3}{|c|}{86.25} \\
\hline & $\mathrm{CV}$ & \multicolumn{3}{|c|}{19.08} \\
\hline \multirow{4}{*}{42} & Minimum & $1089 \mathrm{bc}$ & $760.3 \mathrm{a} \quad 761.7 \mathrm{a} \quad 994.9 \mathrm{~b}$ & $1076 \mathrm{bc}$ \\
\hline & Maximum & $694.5 \mathrm{a} \quad 757.6 \mathrm{a}$ & 778.1 a $\quad 860.5 \mathrm{ab} \quad 1199 \mathrm{c}$ & $1307 \mathrm{c}$ \\
\hline & LSD 5\% & \multicolumn{3}{|c|}{194.6} \\
\hline & CV & \multicolumn{3}{|c|}{10.08} \\
\hline \multirow{4}{*}{56} & Minimum & $1374 \mathrm{bc}$ & $1015 \mathrm{ab} \quad 965.7 \mathrm{ab} \quad 1181 \mathrm{~b}$ & $1542 \mathrm{c}$ \\
\hline & Maximum & $874.3 \mathrm{a} \quad 1108 \mathrm{ab}$ & 860.9 a 1291 bc $1563 \mathrm{c}$ & $1238 \mathrm{~b}$ \\
\hline & LSD 5\% & \multicolumn{3}{|c|}{265.8} \\
\hline & CV & \multicolumn{3}{|c|}{10.70} \\
\hline \multirow{4}{*}{70} & Minimum & $1841 \mathrm{ab} \quad 1294 \mathrm{a}$ & $1786 \mathrm{ab} \quad 1806 \mathrm{ab} \quad 1948 \mathrm{ab}$ & $1823 \mathrm{ab}$ \\
\hline & Maximum & $1532 \mathrm{ab} \quad 1973 \mathrm{ab}$ & $2024 \mathrm{~b} \quad 1486 \mathrm{ab} \quad 1832 \mathrm{ab}$ & $2597 \mathrm{~b}$ \\
\hline & LSD 5\% & \multicolumn{3}{|c|}{682.0} \\
\hline & $\mathrm{CV}$ & \multicolumn{3}{|c|}{17.78} \\
\hline \multirow{4}{*}{84} & Minimum & $4884 \mathrm{~b}$ & $5383 \mathrm{~b} \quad 4399 \mathrm{ab} \quad 4234 \mathrm{ab}$ & $4053 \mathrm{ab}$ \\
\hline & Maximum & $3505 a \quad 4189 a b$ & $4335 \mathrm{ab} \quad 4133 \mathrm{ab} \quad 5786 \mathrm{~b}$ & 3564 a \\
\hline & LSD 5\% & \multicolumn{3}{|c|}{1023} \\
\hline & $\mathrm{CV}$ & \multicolumn{3}{|c|}{11.19} \\
\hline \multicolumn{5}{|c|}{$\begin{array}{l}\text { Remarks: Number followed by the same letter in the same period (days after planting) doesn't } \\
\text { show any significant difference based on LSD test at 5\%; H0: without herbicide; H1: } \\
\text { paraquat herbicide before tillage; H2: paraquat herbicide before planting; H3: } \\
\text { glyphosate herbicide before tillage; H4: glyphosate herbicide before planting; H5: } \\
\text { paraquat+glyphosate herbicide before planting. }\end{array}$} \\
\hline
\end{tabular}

between $20-29 \%$ on fresh weight of roots when combined with minimum tillage system.

The result of analysis of varians indicated that there was interaction between tillage system and herbicide application on fresh weight of leaves. The mean of the fresh weight of leaves influenced by the interaction was presented on table 7 .

Naidu and Haymes (1998) mentioned that physiological prosses of plant roots is affected by soil structure including mineral absorbtion, water absorbtion, and respiration. Soil structure influences mineral and water movement as well as $\mathrm{O}_{2}$ and $\mathrm{CO}_{2}$ circulation in the soil. The main function of plant roots is absorbing water and mineral from the soil. Besides, tillage also makes soil structure become more crumbly so that it will enhance germination and affect infiltration.

\section{Dry weight of chopped tobacco}

The analysis of varians elicited that there was interaction between tillage system and herbicide application on the dry weight of chopped tobacco.
From the research, it was found that maximum tillage combined with glyphosate herbicide application as well as combination between paraquat + glyphosate herbicide gave higher dry weight of chopped tobacco reaching 7.4-38.51\% compared to other treatments. According to Bush (1999) and Tso (1990), roots grow better in light soil. On the other hand, the roots growth is worse in heavy soil (Amato and Ritchi, 2002) since roots need more energy to penetrate the soil (Islami and Utomo, 1995).

\section{Nicotine content}

The analysis of varians showed that there was interaction between tillage system and herbicide application on nicotine content of tobacco's plant. The average of nicotine content affected by the interaction is presented on table 9 .

Nicotine content of tobacco planted on field with minimum tillage system and glyphosate herbicide application before planting was higher compared to that of those planted on field with other treatments reaching $3.86 \%$. This result was slightly higher than 
Table 6. Fresh weight of stems and roots $\left(\mathrm{g} \mathrm{plant}^{-1}\right)$ affected by interaction between tillage system and herbicide application

\begin{tabular}{ccccccc}
\hline Tillage & \multicolumn{6}{c}{ Treatment } \\
\cline { 2 - 7 } system & $\mathrm{H} 0$ & $\mathrm{H} 1$ & $\mathrm{H} 2$ & $\mathrm{H} 3$ & $\mathrm{H} 4$ & $\mathrm{H} 5$ \\
\hline Minimum & $1058 \mathrm{~d}$ & $955.3 \mathrm{~cd}$ & $910.3 \mathrm{c}$ & $608.3 \mathrm{a}$ & $793.0 \mathrm{~b}$ & $1177 \mathrm{e}$ \\
Maximum & $894.7 \mathrm{bc}$ & $1200 \mathrm{e}$ & $1210 \mathrm{e}$ & $1137 \mathrm{de}$ & $1118 \mathrm{de}$ & $910.3 \mathrm{c}$ \\
\hline LSD 5\% & \multicolumn{5}{c}{107.6} \\
CV & \multicolumn{7}{c}{5.134} \\
\hline
\end{tabular}

Remarks: Number followed by the same letter in the same column doesn't show any significant difference based on LSD test at 5\%; H0: without herbicide; $\mathrm{H} 1$ : paraquat herbicide before tillage; $\mathrm{H} 2$ : paraquat herbicide before planting; H3: glyphosate herbicide before tillage; H4: glyphosate herbicide before planting; H5: paraquat+glyphosate herbicide before planting.

Table 7. Fresh weight of leaves $\left(\mathrm{g} \mathrm{plant}^{-1}\right)$ affected by interaction between tillage system and herbicide application

\begin{tabular}{ccccccc}
\hline Tillage & \multicolumn{5}{c}{ Treatment } \\
\cline { 2 - 6 } system & $\mathrm{H} 0$ & $\mathrm{H} 1$ & $\mathrm{H} 2$ & $\mathrm{H} 3$ & $\mathrm{H} 4$ & $\mathrm{H} 5$ \\
\hline Minimum & $2030 \mathrm{~cd}$ & $1180 \mathrm{a}$ & $1898 \mathrm{bc}$ & $1783 \mathrm{~b}$ & $1942 \mathrm{c}$ & $2395 \mathrm{f}$ \\
Maximum & $2188 \mathrm{de}$ & $2045 \mathrm{~cd}$ & $2551 \mathrm{~g}$ & $2085 \mathrm{~d}$ & $2635 \mathrm{~g}$ & $2212 \mathrm{e}$ \\
\hline LSD 5\% & \multicolumn{6}{c}{28.9} \\
CV & \multicolumn{6}{c}{2.955} \\
\hline Remarks: Number followed by the same letter in the same column doesn't show \\
any significant difference based on LSD test at 5\%; H0: without \\
herbicide; H1: paraquat herbicide before tillage; H2: paraquat herbicide \\
before planting; H3: glyphosate herbicide before tillage; H4: glyphosate \\
herbicide before planting; H5: paraquat+olyphosate herbicide before \\
planting.
\end{tabular}

Table 8. Dry weight of chopped tobacco $\left(\mathrm{g} \mathrm{plant}^{-1}\right)$ influenced by interaction between tillage system and herbicide application

\begin{tabular}{ccccccc}
\hline Tilage & \multicolumn{6}{c}{ Treatment } \\
\cline { 2 - 7 } system & H0 & H1 & H2 & H3 & H4 & H5 \\
\hline Minimum & $411.3 \mathrm{~g}$ & $330.7 \mathrm{c}$ & $319.7 \mathrm{bc}$ & $273.7 \mathrm{a}$ & $284.3 \mathrm{a}$ & $378.7 \mathrm{f}$ \\
Maximum & $308.3 \mathrm{~b}$ & $345.0 \mathrm{~d}$ & $440.0 \mathrm{~h}$ & $364.7 \mathrm{e}$ & $444.7 \mathrm{~h}$ & $444.7 \mathrm{~h}$ \\
\hline LSD 5\% & \multicolumn{5}{c}{12.38} \\
CV & \multicolumn{7}{c}{1.629} \\
\hline
\end{tabular}

Remarks: Number followed by the same letter in the same column doesn't show any significant difference based on LSD test at 5\%; H0: without herbicide; $\mathrm{H} 1$ : paraquat herbicide before tillage; $\mathrm{H} 2$ : paraquat herbicide before planting; H3: glyphosate herbicide before tillage; H4: glyphosate herbicide before planting; H5: paraquat+glyphosate herbicide before planting.

Table 9. Nicotine content (\%) affected by interaction between tillage system and herbicide application

\begin{tabular}{ccccccc}
\hline Tillage & \multicolumn{6}{c}{ Herbicide application } \\
\cline { 2 - 7 } system & $\mathrm{H} 0$ & $\mathrm{H} 1$ & $\mathrm{H} 2$ & $\mathrm{H} 3$ & $\mathrm{H} 4$ & $\mathrm{H} 5$ \\
\hline Minimum & $2.164 \mathrm{c}$ & $3.222 \mathrm{e}$ & $1.418 \mathrm{~b}$ & $2.089 \mathrm{c}$ & $3.863 \mathrm{f}$ & $2.191 \mathrm{~d}$ \\
Maximum & $1.821 \mathrm{c}$ & $1.073 \mathrm{a}$ & $1.023 \mathrm{a}$ & $1.430 \mathrm{~b}$ & $2.258 \mathrm{~d}$ & $2.493 \mathrm{~d}$ \\
\hline LSD 5\% & \multicolumn{7}{c}{0.368} \\
CV & \multicolumn{7}{c}{8.411} \\
\hline
\end{tabular}

Remarks: Number followed by the same letter in the same column doesn't show any significant difference based on LSD test at 5\%; H0: without herbicide; $\mathrm{H} 1$ : paraquat herbicide before tillage; $\mathrm{H} 2$ : paraquat herbicide before planting; H3: glyphosate herbicide before tillage; H4: glyphosate herbicide before planting; H5: paraquat+glyphosate herbicide before planting. 
that of Muryadi et al. (1991) which mentioned that nicotine content of Virginia tobacco was $1.5-3.5 \%$. It can be caused by several factors i.e. application of fertilizer containing high content of $\mathrm{N}$ (above 20\%). Although planting space used in the research was quite narrow $(90 \times 60 \mathrm{~cm})$ with population of \pm 18.000 plants ha ${ }^{-1}$, basically nicotine content of tobacco produced in this research was higher than those produced by Tso (1999) mentioning that tobacco's plant population of 16.000 plants ha ${ }^{-1}$ produced nicotine content as much as $2.19 \%$.

Besides, the type of the field used in this research was previously planted with rice. It was in accordance with Leffingwell (1999) who stated that in heavy soil, nicotine content will be lower than that in clay soil, and nicotine content tends to increase in higher site.

\section{CONCLUSION}

Herbicide application before planting, either glyphosate or paraquat, was able to suppress the weed growth on tobacco's plantation. Application of herbicide containing glyphosate before planting could improve tobacco's growth element such as number of leaves, plant height, and leaf area. Application of herbicide containing glyphosate both before tillage and before planting was able to enhance yield component of tobacco's plant including fresh weight of roots, stems, and leaves, dry weight of chopped tobacco, and nicotine content.

\section{REFERENCES}

Amato, M. and J.T. Ritchie. 2002. Spatial distribution of roots and water uptake of maize (Zea mays) as affected by soil structure. Crop Sci., 42. pp.773-780

Badan Pusat Statistik. 2014. Produksi Perkebunan Besar menurut Jenis Tanaman. Jakarta

Blum, R. R. J. I. Isgrigg and F. H. Yelverton. 2000. Purple (Cyperus rotundus) and yellow nutsedge (C. esculentus) control in Bermuda grass (Cynodon dactylon). Weed Technol., 14(2): pp. 357-365.

Bush, L. P. 1999. Alkaloid Biosynthesis In. Davis, D. L. and M. T. Nielsen (eds.). Tobacco: Production, Chemistry, and Technology. Oxford: Blackwell Science, pp. 285-291

Chinery, D. 2002. Using Acetic Acid (Vinegar) as a Broad-Spectrum Herbicide. Cooperatif Extension Educator, Cornell Cooperative Extentsion of Rensselaer Country, 61 state street, New York. Also available $h t t p: / / w w w . c c e r e n s-$ selaer.org/horticulture-program/Turfgrass-
Research/Vinegar-Herbicide.aspx

Daud, D. 2004. Uji efikasi herbisida glyphosate, sulfosat dan paraquat pada sistem tanpa olah tanah (TOT) jagung. Dalam Prosiding Seminar Ilmiah dan Pertemuan Tahunan PEI PFI XIX Komisariat Daerah Sulawesi Selatan, 5 November 2008. pp. 21-28

Direktorat Jenderal Perkebunan. 2013. Produksi Tembakau menurut Provinsi di Indonesia. Jakarta

Hassan, M. O.; N.H. Gomma; G.M. Fahmy; L. Gonzalez; O. Hammouda and A.M. Atteya. 2014. Interactions between Sonchus oleraceus L. and some weeds in agroecosystems in Egypt. Annals of Agric. Sci. 59(2): pp.221-228

Holm, L. G. 1977. Some Characteristic of Weed Problems in the World, Proc. West. Soc. Weed Sci.: 3-12

Islami, T. and W.H. Utomo. 1995. Hubungan tanah, air,dan tanaman. Semarang: IKIP Semarang Press.

Leffingwell, J. C. 1999. Leaf Chemistry: basic chemical constituent on tobacco leaf and differences among tobacco types. Blackwell Science Ltd. pp. 265-284

Moenandir, J. 2004. Prinsip-prinsip utama menyukseskan produksi pertanian. Malang: Bayumedia Publ., pp. 60-66

Murdiyati, A.S.; A. Herwati and Suwarso. 2009. Pengujian Efektivitas Penggunaan Pupuk ZK terhadap Hasil dan Mutu Tembakau Madura. Buletin Tanaman Tembakau, Serat dan Minyak Industri. 1(1): pp.45-55

Naidu, R. and R. J. Haynes. 1998. Influence of lime,fertilizer and manure applications on soil organic matter content and soil physical conditions: a review. Nutrient Cycling in Agroecosystems, 51: pp.123-137

Sukma, Y. and M.S. Yakup. 1995. Gulma dan Teknik Pengendaliannya. Jakarta: PT. Raja Grafindo Persada.

Tjitrosoedirdjo, S.; W. H. Utomo, and J. Wiroatmojo. 1984. Pengelolaan Gulma di Perkebunan. Jakarta: Penerbit Gramedia, pp. 34-56

Tso, T. C. 1990. Production, Physiology and Biochemistry of Tobacco Plant. Beltsville: Ideals. Inc., pp. 55-65. 